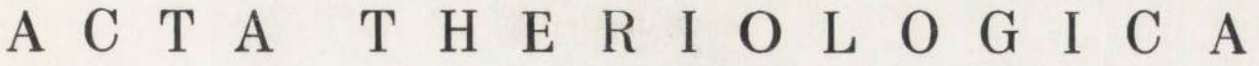 \\ VOL. X, 2: $11-25$ \\ BIAEOWIEŻA \\ 15.VIII.1965
}

\author{
Włodzimierz J E Z I E R S K I
}

\section{Studies on the European Hare. VII. Changes in Some Elements of the Structure and Size of Population}

\author{
[With 9 Figs, \& 4 Tables]
}

\begin{abstract}
Examination in the Poznan province was made of 190 samples, totalling 17,516 hares, in $1958 / 58-1961 / 62$ during the period from November 1st to January 10th. Each sample consisted of a day's shoot using beaters to drive the hares, in principle in fields, and only very seldom in woods. Investigation was made of the age structure (by Stroh's method) and sex ratio. Approximate data on populations numbers on March 31st before taking the sample and on March 31st after the sample had been taken, were collected for the areas from which the samples were taken. It was found that sex ratio was $1: 1$ each year. The real increase in young hares from one sexually mature female varied from $2.2-2.4$ young, apart from 1959 , when the figure rose to 2,9 . The period $1959 / 60$ was also the most favourable as regards population abundance and productivity, the latter being about $30 \%$ higher than in $1961 / 62$ and about $45 \%$ higher than in any of the other three study years. The material collected shows that the productivity of the shooting area depends not only on the abundance of the population, but also on the real increase in young hares, which in certain years may also be the direct cause of variations in productivity. It would also seem that the system of shoots using beaters has a selective effect on the age groups of the population, causing a greater reduction in young hares.
\end{abstract}

\section{INTRODUCTION}

The quantitative dynamics of a hare population, and in particular their effect in the form of population numbers, have long since engaged the attention of both practical hunters and biologists. The first publications on this subject appeared in the second half of the 19 th century. It must at once be emphasised that until comparatively recently the views held by many authors were greatly simplified and the suggestions and recommendations they make rouse fundamental objections $(\mathrm{B} \mathrm{u}-$ dzyński, 1953; Szeder jei, 1958; Szczepkowski, 1951; Tilgner, 1950; 1954).

Contemporary ecologists are in agreement as to the fact that the population structure exerts a very important influence on the variations in population numbers of animals (Allee, et al., 1958; Andrzejewski \& Pielowski, 1957; Naumov, 1961; Pielowski, 1961). This question was discussed in detail in relation 
to the hare by Andrzejewski \& Pielowski (1957). It is perhaps worth while devoting a few words to describing the opinions held on these elements of the structure of hare populations with which the present study is concerned.

Research in recent years on the sex structure of hare populations ( $\mathrm{T}$ il $\mathrm{g} \mathrm{n}$ e r, 1950; 1953; Jezierski, 1959; Hel1, 1960; Pielowski, 1961) has thrown a certain amount of light on this question being based on fairly abundant material, but the views of different scientists on this subject are by no means unanimous. $\mathrm{T}$ il g n e r $(1950 ; 1953)$ and $\mathrm{J} \mathrm{e} \mathrm{z} \mathrm{i} \mathrm{e} \mathrm{r} \mathrm{k}$ i $(1959)$ who in their investigations obtained from a large number of samples mean values which did not in principle differ from $1: 1$, point out, however, that the samples from which the mean values were calculated are distributed within limits of values of the ratio of females to males from $2: 1$ to $1: 2$, and even in a few cases come outside these limits. H e 11 (1960), who obtained an average ratio of females to males of $1.43: 1$ from samples supplied by shoots in which the hares were driven within range of the guns. and of $1: 1$ from samples obtained by driving the hares into lines of nets, assumes that this is the result of the difference between the means by which the samples were obtained. He also assumes that a greater amount of male hares than females are calight when netting the animals. His opinion, presented in this way, is in principle exactly the same as the view put forward that the sex ratio differs from 1:1. Finally Pielowski (1961), who cbtained from his examinations of shot hares brought for sale to a state purchasing office a ratio of females to males of $1.16: 1$, which was in fact statisticaliy significant for the numbers of hares examined, expresses the opinion that this is due to the selective effect of shooting hares which have been driven by beaters, while in the animals' natural habitat a ratio of $1: 1$ should be expected. He also makes the point, however, that the possibility cannot be excluded that sex ratio is subject to seasonal changes.

The second, and relatively frequently discussed element of the hare population is the age structure. The majority of authors connect this in a causative way directly with the variations in population numbers. Hediger (1948) on the kasis of research on captive animals, established that reproduction dynamics vary within limits of 8-12 young per one sexually mature femals. Tilg ner (1957) on the above grounds, expresses the view that under Polish climatic conditions the mean annual number of animals born is approximately 9 . Therefore in a thecretically accepted case of complete absence of mortality among the young hares, the age structure of the hare population in Poland should be expressed by the ratio of hares born that year to the older hares of approximately $80: 20$. In Tilgner's opinion the percentage of young hares in very good shooting areas is about $70 \%$, and in shoots with normal age structure $-60 \%$. Finally $\mathrm{R}$ a c z y ń s k i (i964) on the basis of examination of the pregnancies of female hares obtained over a whole year in the Poznan province, reached the conclusion that the number of young born was approximately 7.3 per female. It is of course unnecessary to add that this last opinion, being based on material taken from a free-living population, reflects most accurately the real relations obtaining in the hares' natural habitat and is more convincing than the data taken from examinations of captive animals (Fi e dige r, 1948) or those based on theoretical calculations ( $\mathrm{T}$ ilg n e r, 1954b; 1957a; 1957b).

The aim of the investigations described in the present study was to trace the variations taking place in the age and sex structure and fluctuations in the numbers of a population of the European hare (Lepus europaeus P a 11 a s, 1778). It would 
seem that this type of investigation, as the result of its appropriate modification, can provide a foundation for predicting fluctuations in the population numbers of this species.

\section{INVESTIGATION METHODS}

Data for the present study were collected by means of the questionnaire method covering the whole of the Poznan province, in five consecutive years $(1957 / 58-$ 1961/62). The questionnaire was completed by specially chosen hunters, the personal merits and knowledge of hunting practice of the persons chosen being taken into account. Data for the questionnaire were taken from material shot during shoots with beaters to drive the hares, which were mainly field-dwelling animals, forest hares occurring only rarely. The distribution of samples (shoots) was fortuitous, not proportional as to area and numbers.

Each of the questionnaires, in addition to the general data, such as district, number of hunting area, number of seat of the shooting club and name and address of the person completing the form, also contained detailed data consisting of figures determined for each drive separately: young male hares under one year old, male hares over one year old, young females under and females over one year old. It was only in 1957/58 that data were not collected separately for each drive, but jointly for the whole shoot, and in addition data on sex ratio and age structure were collected separately (i.e. the groups of females and groups of males were not divided into those under one year and over one year old, but the sex and the age structure was noted separately. The latter is of importance for the purposes of the present study only in relation to calculation of the mean real increase in the sample. Also, in $1957 / 58$ the sample covered all the shoots made in the area of the chosen hunting area and in the following years (1958/59-1961/62) it covered only one shoot.

The detailed data in the questionnaire were determined by means of the following methods: the age of the hare by Stroh's method and sex by examining the external genital organs.

In addition, apart from the questionnaire the size of the hare population on March 31st preceding the study period and after the study period was determined for each of the hunting areas investigated (e.g. for investigations in year 1957/58 the clata for March 31st 1957 and for March 31st 1958 were taken into consideration). These data were established by means of a scrutiny of the records kept by the Provincial Hunting Council of the Polish Hunting Union in Poznan and the Agriculture and Forestry Department of the local authorities in Foznań, according to what is known as the game stock-taking for planned shooting purposes (estimate of population numbers).

In order to define the study period, the period of the hunting economic year which begins on April 1st and ends on the following March 31st was accepted, for three reasons. In the first place, samples were taken each year at the turning point between two neighbouring calendar years, to be exact, during the period between November 20 th and January 10th. In the second place this period is at the same time the natural biological year, and in the third when analysing the resuits of samples, the size of the population from which the sample was initially and finally taken on Niarch 31st was determined for each sample. For the above reasons it was convenient to accept such a definition of time, which on the one hand would include the period beginning and ending at the moment of determining the size of the populations examined, and on the other would coincide with the natural cycle of life processes in the population. 


\section{ANALYSIS OF RESULTS}

The summarised numerical results of the samples, relations between each of the sizes, expressed in percentages, and the mean indices of the real increase per one sexually mature female, are illustrated in table 1.

The statistical analysis of data from this table gives the following results:

1. The sex ratio did not reveal any statistically significant difference from the ratio $1: 1$ in any of the five study years over the scale of the whole province. The absence of significance of this difference was checked by comparing the numbers of females and males in each year with the anticipated numbers obtained from the formula:

$$
\mathrm{n} \cdot \mathrm{p}-3_{\mathrm{s}}
$$

where: $n-$ total number of hares examined, $p$ - anticipated proportion, $s-$ standard deviation of numbers.

Table 1.

Summarized results of samples, in numbers and ratios.

\begin{tabular}{|c|c|c|c|c|c|c|c|}
\hline \multirow{2}{*}{ Year } & \multirow{2}{*}{$\begin{array}{l}\text { lumber } \\
\text { of samples }\end{array}$} & \multirow{2}{*}{$\begin{array}{l}\text { Number } \\
\text { of hares }\end{array}$} & \multicolumn{2}{|c|}{$\begin{array}{l}\text { Ratio in } \\
\text { percentages }\end{array}$} & \multicolumn{2}{|c|}{$\begin{array}{l}\text { Number } \\
\text { of hares }\end{array}$} & \multirow{2}{*}{$\begin{array}{l}\text { Mean real } \\
\text { increase }\end{array}$} \\
\hline & & & of́: : $q \uparrow$ & $1: 0$ & 0 q9 & Y & \\
\hline $1957 / 58$ & 29 & 6,420 & $49: 51$ & $52: 48$ & 1,569 & 3,323 & 2.3 \\
\hline $1958 / 59$ & 53 & 3,312 & $47: 53$ & $50: 50$ & 821 & 1,544 & 2.2 \\
\hline $1959 / 60$ & 27 & 2,408 & $50: 50$ & $56: 44$ & 543 & 1,350 & 2.9 \\
\hline $1960 / 61$ & 44 & 2,793 & $52: 48$ & $45: 55$ & 757 & 1,255 & 2.2 \\
\hline $1961 / 62$ & 37 & 2,683 & $50: 50$ & $52: 48$ & 643 & 1,383 & 2.4 \\
\hline Total & 190 & 17,516 & & & & & \\
\hline
\end{tabular}

2. The ratio of hares less than 1 year old $(Y)$ to those over one year old $(O)$, examined in the same way, revealed a ratio of 50:50 for the years $1957 / 58,1958 / 59$ and $1961 / 62$. In $1959 / 60$ this ratio was $56: 44$, thus revealing the preponderance of young hares. The following year the exactly opposite was the case, hares over one year old predominating (45:55).

3 . The mean real increase of young hares from one sexually mature female reveals a significant difference only between the years 1958/59 and $1959 / 60$ ( $t$ Student test given in table 2). It would, however, seem that the statement may be ventured here that in general the real increase in the hares in the year 1959/60 was significantly higher than the increase in each of the four other study years, which exhibited no significant differences between each other. Grounds for such a statement are also provided by the size of the real increase in the year $1960 / 61$, which is identical with that in $1958 / 59$, and also the very small differences, in 
comparison with those years, in the real increase in 1957/58 and 1961/62. This is further borne out by the almost identical variations in real increase and the mean result of the shoot, which are shown in fig 1 . The results of the $t$ Student test should therefore probably be attributed to the relatively small size of the samples in certain of the years.

\section{Table 2.}

Results of the $t$ Student test for differences between real mean increases in young hares ciuring the period from 1957/58 - 1961/62.

\begin{tabular}{|l|c|c|c|c|c|}
\hline Year & $\begin{array}{c}1957 / 58 \\
1958 / 59\end{array}$ & $\begin{array}{c}1957 / 58 \\
1959 / 60\end{array}$ & $\begin{array}{c}1957 / 58 \\
1960 / 61\end{array}$ & $\begin{array}{c}1957 / 58 \\
1961 / 62\end{array}$ & $\begin{array}{c}1958 / 59 \\
1959 / 60\end{array}$ \\
\hline $\begin{array}{l}\text { t Student test } \\
\text { Number of degrees } \\
\text { of freedom }\end{array}$ & 0.27 & 1.83 & 0.28 & 0.35 & 2.07 \\
Frobab1lity & 79 & 54 & 69 & 65 & 77 \\
\hline Year & 0.2 & 0.9 & 0.2 & 0.3 & 0.96 \\
\hline $\begin{array}{l}\text { t Student test } \\
\text { Number of degrees } \\
\text { of freedom } \\
\text { Probability }\end{array}$ & $1958 / 59$ & $1958 / 59$ & $1959 / 60$ & $1959 / 60$ & $1960 / 61$ \\
\hline
\end{tabular}

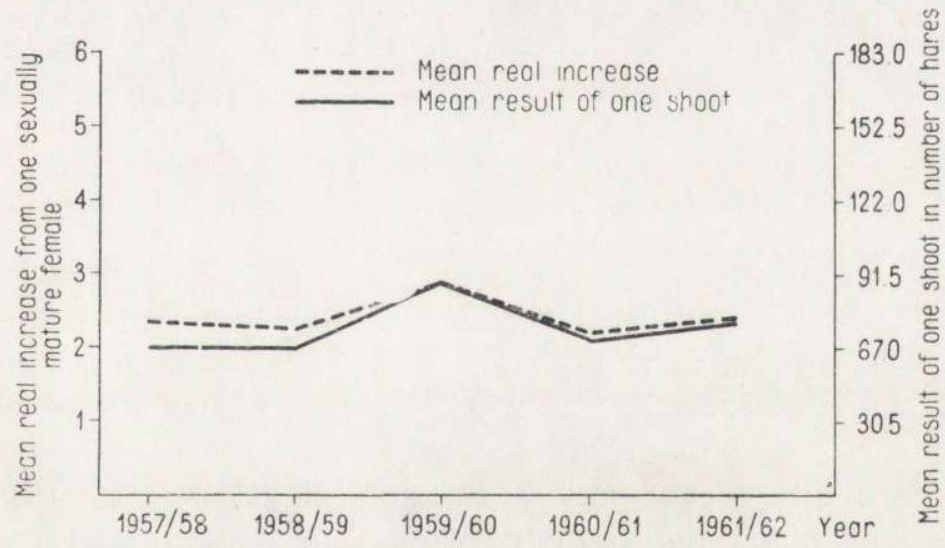

Fig. 1. Curves of variations in the mean real increase and mean result of one shoot.

The two distributions illustrating the sex structure (percentage of females in each sampie) shown in fig. 2 are strikingly symmetrical, almost identical in all the years. The curves of these distributions differ from the curve of normal distribution in principle only as to their leptocercal appearance, which is in fact characteristic of statistics obtained from small samples.

Fig. 3 shows the percentage of young hares in each sample (age structure of the population). After the slightly positively oblique course of the distribution characterising $1957 / 58$, the year $1958 / 59$ has a distribut- 
ion which is very slightly negatively oblique. The following two years are characterised by distributions which are distinctly oblique, but while that of $1959 / 60$ exhibits a distinct positively oblique course, that of $1960 / 61$ exhibits an equally distinct negative obliquity. Finally the distribution characterising $1961 / 62$ is very similar in its course to the leptocercal normal distribution, with only a slight tendency to positive obliquity. These distributions would seem to point to the fact that $1959 / 60$ was clearly more favourable to increase than the other study years, while $1960 / 61$ was decidedly unfavourable to it.

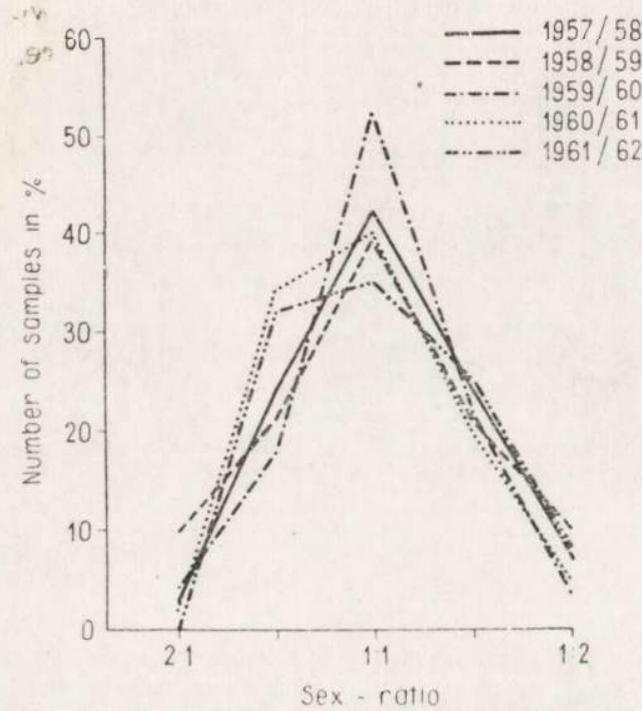

Fig. 2. Curves of distribution of the sex structure of a population.

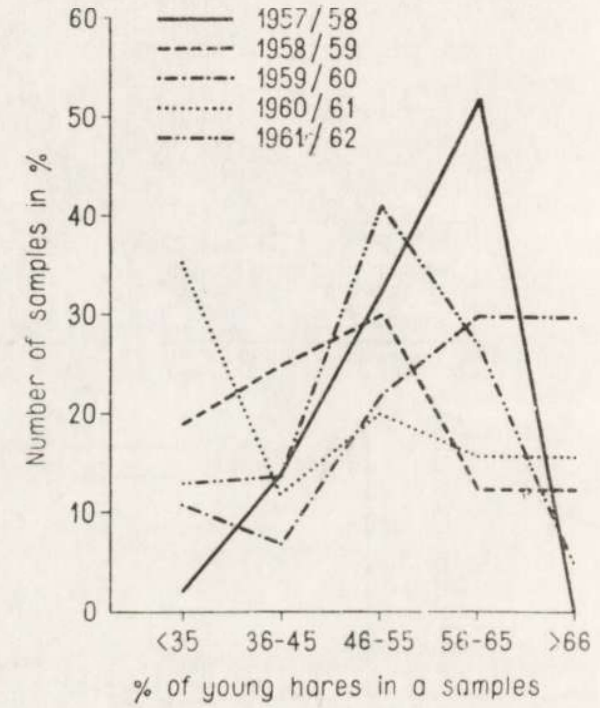

Fig. 3. Curves of distribution of the age structure of a population.

Fig. 4 presents the second aspect of the age structure of a population, that is, the real increase of young hares per one sexually mature female. The year $1959 / 60$ is characterised here by a curve similar to the normal distribution, while the distributions of the other study years have a decidedly negatively oblique course. When examined by means of the coefficient of variation these distributions exhibit distinct evenness in $1959 / 60$ and a concentrative character. As it had already been shown that $1959 / 60$ was distinctiy more favourable to increase than the other study years, this made it possible to put forward the hypothesis that in the so-called bad hare years a high real increase in the number of hares occurs in certain in which the habitat conditions are specifically favourable to the hare, or where there is a particular system of intrapopulation relations which predestinates a large number of births or low mortality rate. In the 
remaining areas the real increase is then low, probably in connection with the occurrence of reducing factors. On the other hand a good hare year is characterised by high real increase in the number of young hares in all the areas, possibly as the result of the absence or weak influence of reducing factors. It must be added that distributions characterising the real increase of young hares from one sexually mature female do not exhibit a clearly unfavourable increase tendency of 1961/62.

The question of the connection between the mean real increase from one mature female and the mean number of hares shot during a single shoot was examined (Fig. 1). The agreement between the courses of the two curves is completely obvious here. This indicates that the number of hares shot during one shoot is in proportion to and to a great degree dependent

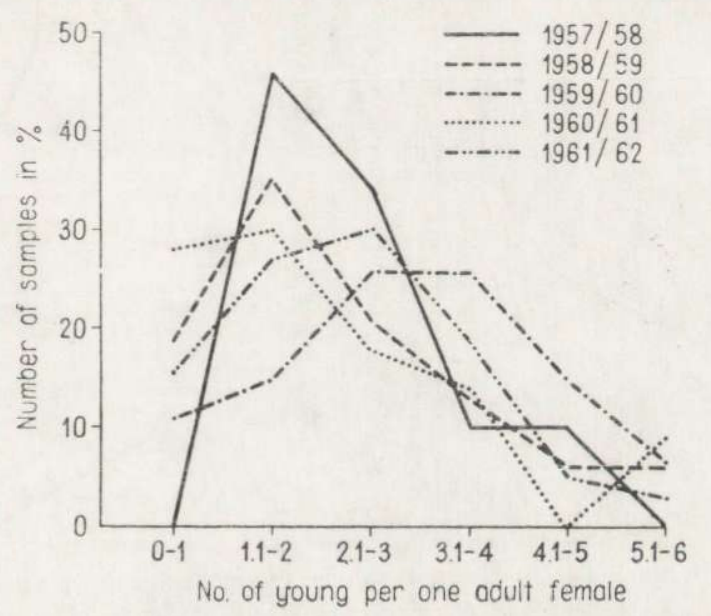

Fig. 4. Curves of variation in the mean real increase.

on the size of the real increase. In order to make the matter even clearer it is perhaps worth adding that the mean number of hares per shoot was as follows in the different years: $1957 / 58-61$ hares, $1958 / 59-61$ hares, 1959/60 - 89 hares, 1960/61 - 63 hares and in 1961/62 - 72 hares.

The next element to be analysed is the size of the populations examined. Two figures, defining the size of the population from which the sample was taken, were obtained for each study area. Distributions of the values of these data, expressed in percentages, are illustrated in figures 5-9. Curves of distributions of size determined for March 31st in 1957, 1958 and 1959 exhibit a course with a distinct tendency to negative obliquity, and therefore samples with a small number of hares are most abundantly represented in them. Analogical distributions for 1960 take a course with an almost horizontal tendency in relation to axes $x$, which indicates that 


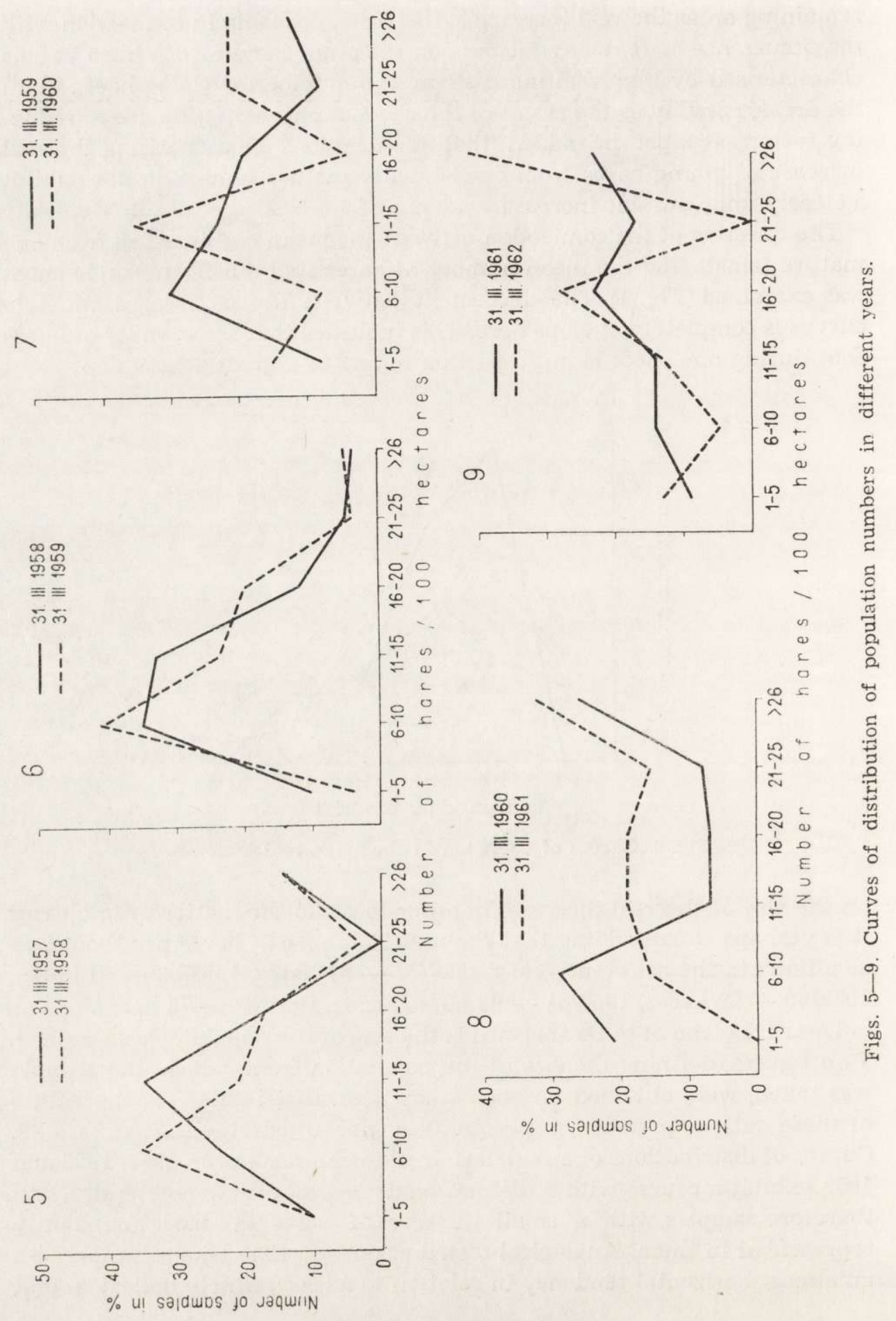


the samples, both larger and smaller, are quantitatively balanced. Finally the distributions from 1961 and 1962 have a distinctly positively oblique course (that of 1962 being probably the mosit positively so). Interpretation of the course described of the curves in different years can, of course, lead only to the finding that after $1957 / 58$ and $1958 / 59$, in which years population numbers were maintained on approximately the same level, the first distinct increase in population numbers occurred in 1959/60, after which a further increase took place in $1960 / 61$. The slightly more positively oblique course of distribution on March 31st 1962 (year 1961/62) cannot be interpreted as the expression of further population increase, as the differences are too small. It is more the expression of the hare population numbers being maintained on the same level as in 1960/61. It will be necessary to return to this question later in the present discussion.

Agreement was also observed in the course taken by distributions of numbers determined at the same time in other study areas (hunting areas). This applies to the distributions of numbers: on March 31st 1958 in figs. 5 and 6, on March 31st 1959 in figs. 6 and 7, on March 31st 1960 in figs. 7 and 8 and on Narch 31st 1961 in figs. 8 and 9. Since each of these five figures illustrates a group of slightly different areas, the distinct agreement in the tendency of the course taken by the above distributions must strengthen confidence in their being truly representative. It must at once be stated here that in order to check whether the estimates of the size of the hare populations examined relatively correctly estimate the numbers, calculation was made of the coefficient of correlation between the numbers of the populations examined and the results of shoots organised in these populations. It was assumed as a starting point that the result of a shoot to a certain extent reflects the populatiton density. This coefficient was $r=0.45$ and was statistically significant for the number of samples obtained. It must therefore be stated that there is a connection between the factors examined, in which connection it may be concluded that the estimates of population numbers obtained are correct in their own way.

To conclude this analysis of the results obtained it is necessary to return once again to the interpretation already given of the tendency in the course of distributions of hare population numbers, particularly in connection with the sufficient degree of correctness attributed to them. At first glance it might be assumed that there is a certain contradiction between the continued growth shown in population numbers in 1960/61 (date of determination of this increase - March 31st 1961), and the depression in the increase of the young hares found in this year (period of increase - spring and summer 1960). This contradiction is, however, only apparent. It must not be forgotten that the increase in $1959 / 60$, which is 
about $30 \%$ higher, considerably reinforced the initial population numbers and in connection with the principle that the population on only half the territory is used for shoots, this increase was not reduced by shooting. As a result the higher initial population numbers in 1960/61 were able to contribute to a further increase in the population, despite the decrease in real population growth. The maintenance of population numbers on the same level in 1961/62 should surely be explained not only by the low increase in that year, but that in 1960/61 as well. The acceptance of such an explanation leads, of course, to the supposition that an increase of about two young per one sexually mature female constitutes an equivalent in quantity to the winter reduction in the population, thus ensuring only

Table 3.

Variations in mean productivity of hare shooting areas from 1957/57 - 1961/62.

\begin{tabular}{|c|c|c|c|c|c|c|}
\hline \multicolumn{2}{|c|}{ Year } & $1957 / 58$ & $1958 / 59$ & $1959 / 60$ & $1960 / 61$ & $1961 / 62$ \\
\hline Mean productivity & n & 61 & 61 & 89 & 63 & 72 \\
of shooting area & $\%$ & 100 & 100 & 146 & 103 & 118 \\
\hline
\end{tabular}

Table 4.

Results of the $t$ Student test for differences between mean values of productivity of shooting areas - from $1957 / 58-1961 / \mathbf{b}^{2} 2$

\begin{tabular}{|l|c|c|c|c|c|c|}
\hline Year & $\begin{array}{l}1957 / 58 \\
1958 / 59\end{array}$ & $\begin{array}{l}1957 / 58 \\
1959 / 60\end{array}$ & $\begin{array}{l}1957 / 58 \\
1960 / 61\end{array}$ & $\begin{array}{l}1957 / 58 \\
1961 / 62\end{array}$ & $\begin{array}{l}1958 / 59 \\
1959 / 60\end{array}$ & $\begin{array}{l}1958 / 59 \\
1960 / 61\end{array}$ \\
\hline $\begin{array}{l}\text { t Student test } \\
\text { Number of degrees } \\
\text { of freedom }\end{array}$ & 0.171 & 3.324 & 0.495 & 2.072 & 2.840 & 0.534 \\
Probability & 158 & 133 & 150 & 143 & 81 & 98 \\
\hline Year & 0.1 & 0.999 & 0.4 & 0.95 & 0.99 & 0.4 \\
\hline t Student test & $1958 / 59$ & $1959 / 60$ & $1959 / 60$ & $1960 / 61$ & & \\
$\begin{array}{l}\text { Number of degrees } \\
\text { of freedom }\end{array}$ & $1961 / 62$ & $1960 / 61$ & $1961 / 62$ & $1961 / 62$ & & \\
Probability & 1.550 & 2.599 & 1.467 & 1.154 & & \\
\hline
\end{tabular}

the continuation of the population on an unaltered numerical level. An increase in population numbers may on the other hand be expected only with a real increase of about 3 hares per one sexually mature female.

The contradiction which occurs between the continued increase in population numbers shown for 1960/61 and the decrease in the same year in the yield from the hare shooting grounds differs slightly from the above. Table 3 gives the variations in the mean yield of hare shooting grounds (mean result of one shoot) in each of the study years. The statistical significance of differences between these mean values was checked by means of the $t$ Student test, the result of this test being given in table 4 . From these tables it is clearly evident that in the first three years the 
tendency in productivity variations takes the same direction as the tendency of the variations in population numbers. In 1960/61, however, the picture changes and despite continued increase in population numbers productivity falls by $43 \%$ in relation to the preceding year, to rise in the following year by $15 \%$, despite the fact, as shown previously, that population numbers were maintained on the same level. The explanation for this must be sought for in the exact proportionality of the results of shoots to the real increase in the numbers of young hares. As, however, a significant connection occurs between the results of shoots and the population numbers it must be stated that the result of the shoot (productivity of the hunting ground) depends on both the population numbers and on the real increase in the number of young hares. In the latter case it is presumably so because a higher percentage of the young hares under one year old is more liable to be shot than the older hares. Attention has already been drawn to objections of this kind by Andrze jewski \& P i e lowski (1957) and also S z e d e r je i (1958) and Hell (1960). It would seem that fig. 4 partly confirms the assumptions of the above authors.

To sum up - if the variations in numbers are large they undoubtedly exert a decisive influence on the productivity of the shooting area. If, however, variations in numbers are slight, while on the other hand the variations in real increase are large, as is the case in the instance discussed, the real increase may have a decisive effect on the mean number of hares killed during one shoot.

\section{DISCUSSION OF METHODS AND RESULTS}

Collection of material for the questionnaire which formed the basis of the present study was undoubtedly burdened with certain errors, both subjective and objective, A fundamental subjective error is the estimate of populatiton size during the process of game "stock-taking" (estimate of population numbers for economic planning purposes). In theory the error in the estimate of numbers may be directed both ways. However in the first place the number of such estimates in the investigations described is small (190 estimates), and in the second it would seem that in practice this error will tend to give a higher number of hares on account of the predisposition of the estimator, for whom this estimate affects the number of animals planned for shooting. Nevertheless correlative checking the estimates of population numbers with the results of shoots and comparison of the course taken by curves of the distribution of population numbers obtained during the same period but on slightly different groups of hunting areas makes it possible to assume that the estimates of population numbers at the author's disposal are reasonably accurate. 
An error has also been made in defining the age according to the so-called Stroh's mark, which disappears between the eighth and ninth month of the hare's life. As a result this mark may not be perceptible in a certain number of young hares born in March. This error should, however, affect the results given here only to a very slight degree. In view of the fact that the so-called March hares form scarcely $13 \%$ of the total increase (P e trov \& D r a g e v, 1962) and that this error does not apply to all the hares born during this period it may be taken that the extent of this error in the present investigation should fluctuate between limits of $3-5 \%$, bringing about, of course, a reduction in the number of young hares. It must be pointed out here, however, that Pi elowsk i (1961) when examining game brought to a purchasing centre in December 1958, obtained out of a total number of 1098 hares examined in the Poznan province a different age relation from that determined in the present study, that is, the ratio of young to old hares established by the above author was 33:67. It is difficult to explain this fact at the present time. It may result from $\mathrm{P}$ i e lo w s ki's (1961) investigations having been carried out at the end of December, while those presented in the present paper started at the beginning of November, and therefore the March hares might have been classified in the group of old hares. The differences might also be due to Pielowski's data (1961) having been based on the estimates of a qualified research worker, whereas in the present study they were supplied by hunters. Finally it is possible that a certain number of young hares, lighter in weight (for which a correspondingly lower price is paid) were kept by the hunters for their own use, and thus the picture of the real age relations was slightly distorted. It is most probable that the cause of the differences which occurred is the coincidence of all the above possibilities.

The final question to be discussed is the extent to which the results obtained are representative of the real relations prevailing in the populations. This question has two aspects.

The first of the number of samples sufficient to obtain the required degree of correctness of conclusions. It is possible that the number of samples from 1957/58 and 1959/60 are rather small (less than 30 samples) for the purposes of statistical analysis of the interdependences (correlations), and for the significance of differences between mean values ( $t$ Student test). Correlations were, however, calculated jointly for the whole five-year study period (190 samples), and figure 1 is primarily evidence of the significance of the differences between mean values. The results obtained were therefore taken as sufficient for the interpretation accepted.

The second aspect of the representative character of the results obtained is the objection, which may be reduced to the general statement that all 
differences in the reaction of the hare to the hunter caused by sex and age differences or by different ways of carrying out the shoot may as a result give a different percentage of hares shot in each age or sex group from that existing in the area. This question has been discussed in greater detail by A nd r z e j e ws k i \& P i e low ski (1957), and certain aspects of this problem have been dealt with by $\mathrm{Hell}(1960)$ and $\mathrm{Szederjei}$ (1958). In the material presented in this study these theses would seem to be confirmed in as far as the selective action of shooting driven game on different age groups is concerned. It is therefore only necessary to stress the lack of any other method permitting of investigating a larger number of hares in varied areas, and also the fact that, although the results obtained probably do not reflect the actual relations in absolute figures, y'et when collected over several periods they undoubtedly enable the variations taking place to be assessed.

\section{$\therefore \quad$ REFERENCES}

i. Alle e, W. C., Emer son, A. E., Park, O., Park, T. \& Schmidt, K. P., 1958: Zasady ekologii zwierząt. Państw. Wyd. Nauk. 1: 1-598. Warszawa.

2. Andrzejewski, R. \& Pielowski, Z., 1957: O konieczności pogłębienia badań populacyjnych nad zającem (Lepus europeus Pa 11.). Ekol. pol., B, 3, 4. 293-298. Warszawa.

2. Bu dzyński, E., 1953: Zając, hodowla i polowanie. 1-39. Państw. Wyd. Roln. i Leśne. Warszawa.

4. He dig er, H., 1948: Die Zucht der Feldhasen (Lepus europeus P a il.) in Gefangenschaft. Physiol. comp. et oecol., 1, 1: 46-62. Haag.

5. H e 1 1, P., 1960. Pomer pohlavia u zajaca (Lepus europaeus P a 11.). Zool. listy, 1: 83-88.

6. Je z i e r ski, W., 1959: Wyniki badań nad zającem w województwie poznańskim. Łowiec pol., 18 (1117): 2-4. Warszawa.

7. Na u mov, N. P., 1961: Ekologia zwierząt. Państw. Wyd. Roln. i Leśne. 1-569. Warszawa.

8. Petrov, P. \& Dragoev, P., 1962: Proučvanja virhu ujakoj momenti od razmnožavaneto na zajaka v Bulgarija. Izv, na Cnii za Gorata, 10: 143-168. Sofia.

9. Pielowski, Z., 1961: Z badań ekologicznych nad zającem. Łowiec pol., 12 (1159): 4-5. Warszawa.

10. R a c zy ński. J., 1964: Studies on the European hare. V. Reproduction. Acta theriol, $9,19: 305-352$.

11. Szeder jei, A., 1958: Z węgierskich badań nad zającem. Łowiec pol., 19-20 (1095-1096): 3, 13: 2-3. Warszawa.

12. Szczepkowski, J. J., 1951: Metody intensyfikacji ilostanów zajęczych. Łowiec pol., 11 (966): 2-5. Warszawa.

13. Thungen, V., 1911: Obręby i parki zajęcze. Łowiec pol. 5-30.

14. Tilgn e r, D. J., 1950: Wydajność i selekcja zajęcy. Łowiec pol., 10 (983): 12-16. Warszawa.

15. Tilg n e r, D. J., 1953: Ilość i jakość zająca gdańskiego. Łowiec pol., 5 (1014): $72-$ 73. Warszawa. 
16. Tilgn e r, D. J., 1954a:,Klatkowa hodowla zajęcy. Łowiec pol., 5 (1026): 10-11. Warszawa.

17. Tilgn e r, D. J., 1954b: Zly rok zajęczy. Łowiec pol., 11 (1032): 6. Warszawa.

18. Tilgne r, D. J., 1954c: Rozpoznawanie wieku zajęcy. Łowiec pol., 12 (1033): 3. Warszawa.

19. Tilgn e r, D. J., 1957a: Nowe obserwacje nad zającem. Łowiec pol., 7-8 (10641065): 4-5, 4-5. Warszawa.

20. Tilg n e r, D. J., 1957b: Bilans przyrostu zajęczego. Eowiec pol., 13-14 (10701071): $10-11,10-11$. Warszawa.

Polish Hunting Association,

Research Station,

Czempiń n/Poznań.

Włodzimierz JEZIERSKI

\section{BADANIA NAD ZAJĄCEM SZARAKIEM. VII. ZMIENNOSĆ NIEKTÓRYCH ELEMENTOW STRUKTURY I LICZEBNOSCI POPULACJI}

\section{Streszczenie}

Materiały do niniejszej pracy zbierano na terenie województwa poznańskiego w latach 1957/58 - 1961/62, w czasie od 1 listopada do 10 stycznia. Ankietę wypelniali społeczni współpracownicy Stacji Naukowo-Badawczej PZ£ w Czempiniu na podstawie materialu odstrzelonego na polowaniach zbiorowych prowadzonych systemem pędzeń, w zasadzie polnych rzacko tylko leśnych. Każda ankieta, oprócz danych ogólnych, zawierała dane szczegółowe co do ilości: samców tegorocznych, samców starszych niż jeáen rok, samic tegorocznych i samic starszych niż jeden rok ustalone dla każdego pędzenia osobno. Wiek zajęcy określano metodą Stro h'a a pleć przez oględziny zewnętrznych narzadów płciowych.

Sumaryczne wyniki ilościowe, stosunki pomiędzy poszczególnymi liczebnościami wyrażone w procentach oraz średnie wskaźniki realnego przyrostu na jedną płciowo dojrzałą samicę, obrazuje tabela 1.

Analiza zebranego materiału pozwoliła sformulować następujące wyniki pracy:

1. Stosunek płci określony dla województwa poznańskiego za pomocą prób pobieranych drogą odstrzału na polowaniach pędzonych nie wykazuje na przestrzeni lat 1557/58 - 1961/62 żadnych zmian i układa się jak 1:1 (tabela 1. rycina 2).

2. Stosunek zajęcy tegorocznych do starszych w latach $1957 / 58,1958 / 59$ i 1961/62 utrzymywał się na tym samym poziomie i wynosil 50:50. W roku 1959/60 grupa wiekowa zajęcy tegorocznych wykazała tendencję zwyżkową (56:44). W roku 1960/61 stosunek zajęcy tegorocznych do starszych wynosił 45:55 (tabela 1, rycina 3).

3. Realny przyrost mlodzieży od jednej plciowo dojrzałej samicy w latach $1957 / 58$, 1958/59, 1960/61 i 1961/62 nie wykazal statystycznie istotnej różnicy i układał się na poziomie $2,2-2,4$ szt. W roku $1959 / 60$ przyrost ten wykazał tendencję zwyżkową i wynosił 2,9 szt. (tabela 1 , rycina 4 ).

4. Rok $1959 / 60$ był zdecydowanie korzystniejszy pod względem liczebności populacji zajęczych niż trzy lata poprzednie. W roku 1960/61 obserwowano dalszy wzrost liczebności populacji zajęczych, które w roku następnym utrzymują się dalej na tym samym poziomie iiościowym (ryciny $5-9$ ). 
5. Liczebność populacji zajęczych jest zależna nie tylko od przyrostu młodzieży aktualnego roku, lecz również od przyrostu mlodzieży w roku poprzeđnim.

6. Ocena liczebności populacji zajęczych dokonywana przez zarządy kół łowieckich wydaje się dla celów praktyki łowieckiej wystarczająco rzetelna.

7. Rok 1959/60 był zdecydowanie korzystniejszy pod względem wydajności łowisk zajęczych niż dwa lata poprzednie. Srednia wydajność łowisk poznańskich w tym roku była o $46 \%$ wyższa niż w którymkolwiek z dwóch lat poprzednich. W r. 1960/61 wydajność lowisk poznańskich znowu spada do poziomu z lat 1957/58 i 1958/59, mimo wzrostu liczebności populacji. W roku 1961/62, mimo braku zmian liczebności populacji, wydajność wzrasta o $15 \%$ (tabela 3 ).

8. Wydajność łowisk zajęczych zależy nie tylko od aktualnej liczebności populacji, lecz również od akitualnego realnego przyrostu młodzieży, do ktćrego wysokości w bacianym olsresie była ściśle proporcjonalna (Ryc. 1). W pewnych latach zmiany wyc’ajności mogą być bezpośrednim skutkiem zmian realnego przyrostu młodzieży.

9. Odstrzał systemem polowań pędzonych wydaje się działać wybiórczo na grupy wiekowe populacji zajęcy, powodując silniejszą ređukcję zajęcy jednorocznych niż zajęcy starszych jak jeden rok. 